https://ojs.umrah.ac.id/index.php/anugerah

\title{
Implementasi Pendidikan Karakter di Lingkungan Keluarga Masyarakat Sebauk, Kota Tanjungpinang
}

\author{
Abdul Malik ${ }^{*}$, Dodi Dahnuss ${ }^{2}$, Isnaini Leo Shanty ${ }^{3}$ \\ 1, 2, ${ }^{3}$ Universitas Maritim Raja Ali Haji, Tanjungpinang, Kepulauan Riau 29124, Indonesia \\ *e-mail korespondensi: datukmalik58@gmail.com \\ Pengiriman: 24 Oktober 2019; Diterima: 21 November 2019; Publikasi: 28 November 2019
}

\begin{abstract}
Abstrak
Kegiatan pengabdian kepada masyarakat ini bertujuan untuk memberikan sosialisasi tentang implementasi pendidikan karakter di lingkungan keluarga masyarakat Sebauk dan memberikan pelatihan kepada masyarakat Sebauk tentang cara mengimplementasikan pendidikan karakter di lingkungan keluarga. Pendekatan yang digunakan dalam bentuk sosialisasi dan implementasi, yang didukung metode ceramah, diskusi, dan pelatihan implementasi dalam keluarga. Hasil pengabdian ini adalah terjadi peningkatan pengetahuan, pemahaman, kemahiran, dan sikap masyarakat Sebauk tentang delapan belas nilai karakter yang harus diterapkan kepada anak-anak di lingkungan keluarga.
\end{abstract}

Kata kunci: sosialisasi; implementasi; pendidikan karakter; keluarga

Abstract

This community service activity aims at socializing the implementation of character education to families in Sebauk community and training families in Sebauk community on how to implement character education. The approach was socialization and implementation through lecture, discussion, and training the family members. The result of this activity was the increase ofknowledge, understanding, skills, and attitudes of Sebauk community about the eighteen character values that must be implemented in educating children in each Sebauk family.

Keywords: socialization; implementation; character education; family

\section{Pendahuluan}

Pendidikan karakter saat ini memang menjadi isu utama pemerintah.Selain menjadi bagian dari proses pembentukan akhlak anak bangsa, pendidikan karakter pun diharapkan mampu menjadi fondasi utama dalam menyukseskan Indonesia Emas 2045. Dalam UU No. 20 Tahun 2003 tentang Sistem Pendidikan Nasional, Pasal 13, ayat 1 dikemukakan bahwa jalur pendidikan terdiri atas pendidikan formal, nonformal, dan informal (Departemen Pendidikan Nasional [Depdiknas], 2003). Pendidikan informal adalah jalur pendidikan keluarga dan lingkungan. Pendidikan informal berperan dan berkontribusi sangat penting dalam keberhasilan pendidikan, terutama dalam pembentukan karakter peserta didik. Pasalnya, 70 persen waktu peserta didik berada dalam keluarga dan masyarakat sekitarnya.

Selama ini pendidikan informal, terutama dalam lingkungan keluarga, belum memberikan kontribusi berarti dalam mendukung pencapaian kompetensi dan pembentukan karakter peserta didik. Ironisnya, justeru karakter individu peserta didik Indonesia malah terasa diambang yang sangat mengkhawatirkan, khususnya di beberapa wilayah negeri ini. Media cetak dan elektronik sering menyoroti rekaman-rekaman yang mengerikan berhubung dengan kekerasan yang dilakukan oleh peserta didik seperti bulan-bulanan (bullying), perampokan, pengedaran narkoba, dan pembunuhan. Selain itu, tawuran-tawuran yang kerap berlaku di kalangan pelajar seperti yang pernah terjadi di Purbalingga.Dalam kasus itu, publik disuguhkan kejadian 
seorang siswa yang menantang gurunya untuk berkelahi di depan kelas. Sebenarnya, masalah ini adalah persoalan bersama dan memerlukan penanggulangan yang cepat. Slogan revolusimental yang dikedepankan oleh Presiden Republik Indonesia pun terasa tak mendapat perhatian yang memadai. Bahkan, realitasyang diperikan di atas, justeru,terjadi pada era slogan itu digaungkan kepada masyarakat.

Pemerintah melalui Kementerian Pendidikan Nasional—sekarang Kementerian Pendidikan dan Kebudayaan - telah menegaskan kebijakan Pendidikan karakter melalui Rencana Aksi Nasional (20102014).Dalam hal ini, pendidikan karakter adalah pendidikan nilai, pendidikan budi pekerti, pendidikan moral, dan pendidikan watak. Tujuannya adalah mengembangkan kemampuan peserta didik untuk memberikan keputusan baik-buruk, memelihara apa yang telah baik dan mewujudkan kebaikan itu dalam kehidupan sehari-hari dengan sepenuh hati (Kementerian Pendidikan Nasional [Kemendiknas], 2010; Pusat Kurikulum, 2010a).

Sejalan dengan itu, Kemendiknas juga menetapkan tiga fungsi pendidikan budaya dan karakter bangsa, antara lain, (1) pengembangan, yakni pengembangan potensi peserta didik untuk menjadi pribadi yang berperilaku baik, yaknibagi peserta didik yang telah memiliki sikap dan perilaku yang mencerminkan budaya dan karakter bangsa, (2) perbaikan,yakni memperkuat kiprah pendidikan nasional untuk bertanggung jawab dalam pengembangan potensi peserta didik yang lebih bermartabat, dan (3) penyaring, yakni untuk menyaring budaya bangsa sendiri dan budaya bangsa lain yang tak sesuai dengan nilai-nilai budaya dan karakter bangsa yang bermartabat (Kemendiknas, 2010; Malik, 2014; Pusat Kurikulum, 2010b).

Untuk menangkal kejadian-kejadian seperti kekerasan yang cenderung terjadi, perlu diupayakan pemahaman cara menanam dan menumbuhkan karakter seperti pendidikan nilai, pendidikan budi pekerti, pendidikan moral, dan pendidikan watak di lingkungan keluarga (Malik \& Shanty, 2017; 2019; Zuriah, 2008). Sejalan dengan tiga nilai itu, secara substantif ada tiga unjuk perilaku yang berkaitan satu sama lain, yakni: (1) moral knowing; (2) moral feeling; dan (3) moral behavior (Lickona, 2004, 2013)

Di samping itu, keluarga merupakan faktor internal yang palingberpengaruh terhadap perkembangan karakter anak. Peran orang tua menjadi mata tombak yang menentukan mampu atau tidaknya seseorang anak menjadi pribadi yang positif. Akan tetapi, ada juga perspektif yang berbeda yang menyatakan bahwa, justeru,penentu seseorang anak menjadi baik atau tidak ada di tangan guru.

Sebagian besar waktu anak dihabiskan di lingkungan keluarga dan lingkungan sekitar mereka. Anakanak merekam semua kejadian yang mereka alami pada suatu hari dan akan selalu tersimpan di dalam memori mereka dengan baik. Hal ini sangat riskan karena yang terekam itu tak semuanya positif. Di sinilah peran orang tua sangat dipelukan untuk mengantisipasi hal tersebut, terutama pengalaman yang negatif (Malik, 2015a).

Penanaman/pendidikan karakter pada anak-anak di lingkungan keluarga sangat perlu dilaksanakan sejak dini (Zubaedi, 2013; Zuriah, 2008). Berhubung dengan itu, kegiatan pengabdian ini difokuskan pada keluarga masyarakat Sebauk, Kota Tanjungpinang.

Kegiatan pengabdian kepada masyarakat inidilaksanakan dengan dua tujuan. Tujuan tersebut adalah untuk (1) memberikan sosialisasi tentang implementasi pendidikan karakter di lingkungan keluarga dan (2) memberikan pelatihan implementasi pendidikan karakter di lingkungan keluarga masyarakat Sebauk, Kota Tanjungpinang.

\section{Metode}

Kegiatan pengabdian kepada masyarakat ini dilaksanakan di RT 002/RW 006 Tanjung Sebauk, Kota Tanjungpinang. Pelaksanaannya berlangsung dari 16 Agustus 2019 sampai dengan 30 Oktober 2019.

Peserta yang hadir dalam kegiatan pengabdian ini 9 orang masyarakat Sebauk. Mereka terdiri atas tokoh agama, tokoh masyarakat, tokoh perempuan, dan tokoh pemuda. 
Pelaksanaan kegiatan meliputi empat aktivitas utama. Pertama, sosialisasi, yakni pelaksana memberikan sosialisasi tentang pendidikan karakter kepada para peserta; kedua, pelatihan implementasi, yakni pelaksana melatih para peserta mengimplementasikan pendidikan karakter kepada anak-anak di lingkungan keluarga mereka; ketiga, penerapan implementasi, yakni para peserta melaksanakan pendidikan karakter kepada anak-anak dan atau adik-adik di lingkungan keluarga mereka masing-masing; dan keempat, pemantauan, yakni pelaksana memantau semua aktivitas peserta dari awal sampai akhir kegiatan seraya melakukan penilaian berdasarkan tanya-jawab, diskusi, dan praktik impelemtasi yang dilaksanakan oleh peserta.

Pendekatan yang diterapkan dengan melaksanakan kegiatan sosialisasi dan implementasi. Implementasi dilaksanakan tiga kali kegiatan dan bertempat di ruang Balai Desa setempat. Kegiatan menggunakan metode ceramah, diskusi, dan pelatihan/praktik imlementasi pendidikan karakter dalam keluarga.

Pelaksanaan pengabdian kepada masyarakat ini berupaya memberikan pemahaman kepada masyarakat Sebauk, Kota Tanjungpinang, khususnya peserta, tentang cara mengimplementasikan pendidikan karakter di lingkungan keluarga. Dengan demikian, diharapkan agar masyarakat, khususnya generasi muda, memiliki moral dan akhlak yang baik melalui penerapan pendidikan karakter yang benar di lingkungan keluarga.

Tolok ukur indikator keberhasilan kegiatan pengabdian masyarakat ini adalah (1) $80 \%$ peserta yang diundang hadir dalam pelatihan ini, (2) terlaksananya seluruh kegiatan pelatihan, (3) pernyataan kepuasan dari peserta pelatihan dan pemerintah setempat, dan $40 \%$ peserta mampu mengaplikasikan ilmu selama pelatihan dengan pendampingan dari tim pengabdian kepada masyarakat.

\section{Hasil dan Pembahasan}

Bentuk kegiatan pengabdian kepada masyarakat ini berupa implementasi pelaksanaan pendidikan karakter di lingkungan keluarga masyarakat Sebauk, Kota Tanjungpinang. Ada delapan belas nilai karakter yang dapat ditanamkan di lingkungan keluarga. Nilai-nilai karakter itu adalah religius, jujur, toleransi, disiplin, kerja keras, kreatif, mandiri, demokratis, rasa ingin tahu, semangat kebangsaan, cinta tanah air, menghargai prestasi, bersahabat/komunikatif, cinta damai, gemar membaca, peduli lingkungan, peduli sosial, dan tanggungjawab (Pusat Kurikulum, 2010a; Zuriah, 2008).

Implementasi pendidikan karakter diintegrasikan dengan kearifan lokal yang terdapat di dalam masyarakat Melayu.Unsur budaya Melayu yang dapat digunakan sebagai bahan pendidikan karakter sangat berlimpah di lingkungan masyarakat, antara lain, (1) lagu mengulik (mendodoikan anak), (2) pantun, (3) syair, (4) gurindam, (5) cerita rakyat, (6) petatah-petitih, (7) tarian tradisional, (8) teater tradisional: bangsawan, mendu, makyong, dan lain-lain (Malik, 2015b; Malik, Harto, \& Saputra, 2017)

Dalam kegiatan ini, narasumber (pelaksana) memberikan materi tentang cara mengimplementasikan pendidikan karakter yang telah disiapkan sebelumnya. Berikut contoh integrasi nilai karakter dalam Gurindam Dua Belas karya Raja Ali Haji, yang disajikan pada Tabel 1. 
JURNAL ANUGERAH. November 2019; I(1): 1 - 7

Tabel 1.

Deskripsi Nilai Pendidikan Karakter dalam Gurindam Dua Belas

\begin{tabular}{|c|c|}
\hline No. Nilai Pendidikan Karakter & Pasal-Pasal Gurindam Dua Belas \\
\hline \multirow[t]{3}{*}{ 1. Religius } & Pasal I, bait $1,2,3,4,5,6$. \\
\hline & Pasal II, bait $1,2,3,4,5$ \\
\hline & Pasal XII, bait 6,7 \\
\hline \multirow[t]{4}{*}{ 2. Jujur } & Pasal III, bait 3 \\
\hline & Pasal IV, bait 3, 5, 9, 11 \\
\hline & Pasal V, bait 2 \\
\hline & Pasal VII, bait $1,3,9,10,11$ \\
\hline \multirow[t]{5}{*}{ 3. Toleransi } & Pasal IV, bait 10 \\
\hline & Pasal V, bait 6 \\
\hline & Pasal VII, bait 5 \\
\hline & Pasal VIII, bait 3,7 \\
\hline & Pasal XI, bait 5 \\
\hline \multirow[t]{2}{*}{ 4. Disiplin } & Pasal III, bait $1,2,3,4,5,6,7$ \\
\hline & Pasal V, bait 6 \\
\hline \multirow[t]{4}{*}{ 5. Kerja keras } & Pasal V, bait 2, 4, 5 \\
\hline & Pasal VI, bait 2 \\
\hline & Pasal VII, bait 6 \\
\hline & Pasal IX, bait 7 \\
\hline \multirow[t]{2}{*}{ 6. Kreatif } & Pasal V, bait 5 \\
\hline & Pasal X, bait 3 \\
\hline \multirow[t]{3}{*}{ 7. Mandiri } & Pasal V, bait 5 \\
\hline & Pasal VII, bait 4 \\
\hline & Pasal X, bait 3 \\
\hline \multirow[t]{6}{*}{ 8. Demokratis } & Pasal IV, bait 8,10 \\
\hline & Pasal V, bait 6 \\
\hline & Pasal VIII, bait 3 \\
\hline & Pasal X, bait 5 \\
\hline & Pasal XI, bait 5 \\
\hline & Pasal XII, bait $1,2,3$ \\
\hline \multirow[t]{3}{*}{ 9. Rasa ingin tahu } & Pasal V, bait 4,5 \\
\hline & Pasal VI, bait 2 \\
\hline & Pasal IX, bait 7 \\
\hline 10. Semangat kebangsaan & Pasal XI, bait $1,2,3$ \\
\hline \multirow[t]{2}{*}{ 11. Cinta tanah air } & Pasal V, bait 1 \\
\hline & Pasal XII, bait 3 \\
\hline 12. Menghargai prestasi & Pasal XII, bait 4,5 \\
\hline \multirow[t]{3}{*}{ 13. Bersahabat/komunikatif } & Pasal VI, bait $1,4,5$ \\
\hline & Pasal VII, bait 9,10 \\
\hline & Pasal X, bait 5 \\
\hline \multirow[t]{7}{*}{ 14. Cinta damai } & Pasal IV, bait $1,2,3,4,8,11$ \\
\hline & Pasal V, bait $1,3,6$ \\
\hline & Pasal VI, bait 1,4 \\
\hline & Pasal VII, bait 9,10 \\
\hline & Pasal VIII, bait 7 \\
\hline & Pasal X, bait 5 \\
\hline & Pasal XI, bait 5, 6 \\
\hline \multirow[t]{2}{*}{ 15. Gemar membaca } & Pasal V, 2, 4, 5 \\
\hline & Pasal IX, bait 7 \\
\hline 16. Peduli lingkungan & Pasal IX, bait 1 \\
\hline \multirow[t]{2}{*}{ 17. Peduli social } & Pasal III, bait 4 \\
\hline & Pasal IV, bait 7 \\
\hline 18. Tanggungjawab & Semua pasal \\
\hline
\end{tabular}


Metode yang digunakan dalam penyampaian materi adalah metode ceramah, tanya-jawab, dan diskusi mengenai proses mengimplementasikan pendidikan karakter di lingkungan keluarga. Dalam ceramah, narasumber (pelaksana kegiatan pengabdian kepada masyarakat) menyampaikan sekaligus mengimplementasikan materi dengan jelas dan terperinci, kemudian dilanjutkan dengan tanya-jawab dan disukusi. Peserta terlihat antusias memperhatikan penjelasan narasumber dan aktif bertanya. Pada saat diskusi, terlihat banyak keluhan yang disampaikan peserta tentang anak-anak mereka yang semakin kurang karakternya dan meminta solusi kepada narasumber berkenaan dengan cara mengatasi hal tersebut. Selanjutnya, dilaksanakan wawancara setelah kegiatan selesai dilaksanakan. Tujuannya untuk mengamati dan menemukan perubahan pengetahuan, pemahaman, kemahiran, dan sikap peserta setelah dilaksanakan kegiatan.

Berdasarkan hasil wawancara, tanya jawab,diskusi, dan pengamatan selama kegiatan berlangsung, kegiatan pengabdian pada masyarakat ini memberikan hasil yang positif. Dalam hal ini, telah terjadi peningkatan pengetahuan, pemahaman, kemahiran, dan sikap orang tua tentang delapan belas nilai karakter dan cara mengimplementasikannya kepada anak-anak berdasarkan kearifan lokal yang ada di dalam masyarakat.

Peningkatan itu meliputi hal-hal yang sangat penting dalam penerapan pendidikan karakter di lingkungan keluarga. Dalam hal ini, terjadi tujuh macam peningkatan sebagai berikut:

1) pengetahuan tentang delapan belas nilai karakter yang harus diterapkan, dari $44 \%$ ke $89 \%$ dengan kenaikan $45 \%$;

2) pemahaman tentang cara mengimplementasikan delapan belas nilai karakter terhadap anak-anak, dari $22 \%$ ke $78 \%$ dengan kenaikan $56 \%$;

3) pengetahuan tentang kearifan lokal yang dapat digunakan untuk menerapkan pendidikan karakter kepada anak-anak, dari $67 \%$ ke $100 \%$ dengan kenaikan 33\%;

4) pemahaman tentang nilai-nilai karakter yang terdapat di dalam kearifan lokal yang tersedia di lingkungan masyarakat, dari $33 \%$ ke $89 \%$ dengan kenaikan 56\%;

5) kemahiran menerapkan nilai-nilai karakter yang terdapat dalam kearifan lokal untuk menularkan nilainilai tersebut kepada anak-anak, dari 33\% ke $78 \%$ dengan kenaikan $45 \%$;

6) kesiapan dan kesadaran tentang tanggung jawab memberikan contoh dan tauladan bersikap, bertutur, dan berperilaku yang berkarakter terhadap anak-anak di lingkungan keluarga, dari 56\% ke 100\% dengan kenaikan $44 \%$;

7) kemahiran memberikan contoh dan tauladan tentang perilaku berkarakter kepada anak-anak di lingkungan keluarga, dari $56 \%$ ke $100 \%$ dengan kenaikan $44 \%$.

Peningkatan pengetahuan, pemahaman, kemahiran, dan sikappeserta tentang delapan belas nilai karakter dan cara mengimplementasikannya kepada anak-anak berdasarkan kearifan lokal yang ada di dalam masyarakat yang diperikan di atas dapat dilihat pada gambar 1 berikut ini.

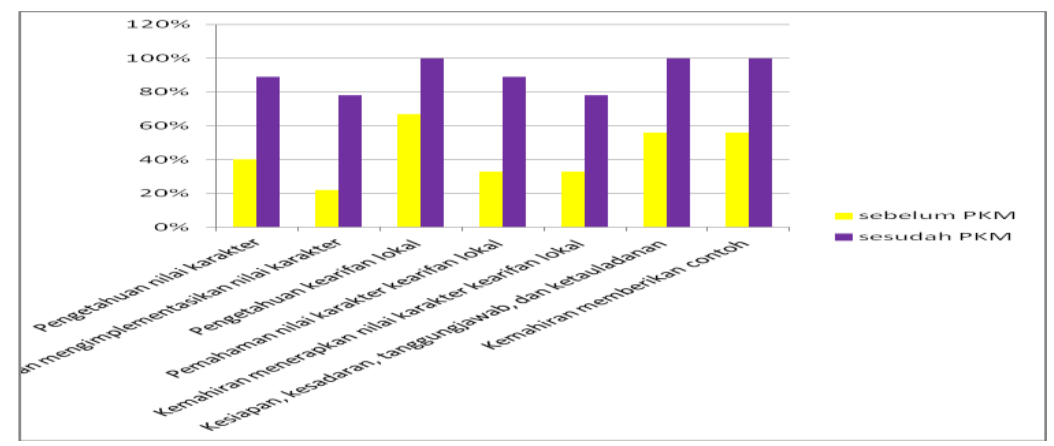

Gambar 1. Diagram pengetahuan, pemahaman, kemahiran, dan sikap orang tua tentang nilai karakter dan cara mengimplementasikannya sebelum dan sesudah PKM 
Berdasarkan data di atas, secara keseluruhan perbandingan pengetahuan, pemahaman, kemahiran, dan sikap peserta tentang delapan belas nilai karakter dan cara mengimplementasikannya sebelum dan sesudah pelaksanaan kegiatan pengabdian kepada masyarakat dapat dilihat pada gambar 2 berikut ini.
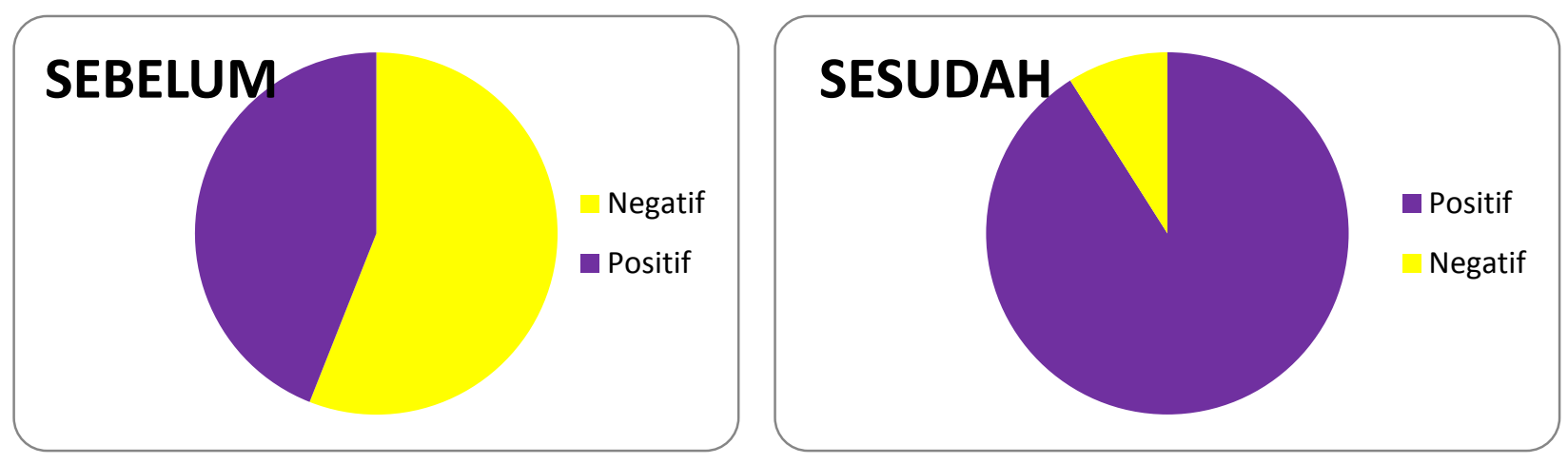

Gambar 2. Diagram perbandingan rata-rata pengetahuan, pemahaman, kemahiran, dan sikap orang tua sebelum dan sesudah kegiatan PKM

Gambar 2 menampilkan keadaan sebelum dilaksanakan kegiatan pengabdian kepada masyarakat,perbandingan pengetahuan, pemahaman, kemahiran, dan sikap orang tua tentang delapan belas nilai karakter dan cara mengimplementasikannya rata-rata yang positif $44 \%$, sedangkan yang negatif $56 \%$. Setelah dilaksanakan kegiatan pengabdian kepada masyarakat, rata-tata yang positifmeningkat menjadi $91 \%$, sedangkan rata-rata yang negatif hanya $9 \%$. Dalam hal ini, terjadi kenaikan rata-rata 47\%. Dengan demikian, kegiatan pengabdian kepada masyarakat ini tergolong berhasil menyosialisasikan implementasi pendidikan karakter di lingkungan keluarga masyarakat Sebauk, Kota Tanjungpinang.

\section{Kesimpulan}

Sesuai dengan perian pada bagian-bagian di atas, kegiatan pengabdian kepada masyarakat ini telah meningkatkan pengetahuan, pemahaman, kemahiran, dan sikap para para peserta di kalangan keluarga masyarakat Sebauk, Kota Tanjungpinang, tentang hakikat dan pentingnya pendidikan karakter diterapkan di lingkungan keluarga dengan kenaikan rata-rata 47\% (dari sebelumnya 44\% menjadi 91\%). Dalam hal ini, kegiatan pengabdian kepada masyarakat ini telah berhasil (1) memberikan sosialisasi dan pelatihan implementasi pendidikan karakter di lingkungan keluarga dan (2) meningkatkan pengetahuan, pemahaman, kemahiran, dan sikap para peserta (orang tua) untuk menjadikan diri mereka sebagai contoh dan atau tauladan utama sosok manusia yang berkarakter baik kepada anak-anak mereka, baik dalam bentuk sikap, ucapan, dan perbuatan dalam kehidupan sehari-hari. Oleh sebab itu, kegiatan pengabdian kepada masyarakat ini harus dilanjutkan di lingkungan yang lain untuk menyosialisasikan dan mengimplementasikan pendidikan karakter kepada masyarakat secara lebih luas. Alhasil, pendidikan karakter benar-benar dapat diterapkan di dalam masyarakat sehingga terbentuk generasi yang berkarakter baik yang dicita-citakan.

\section{Saran}

Berhubung dengan kenyataan yang ditemukan dalam kegiatan pengabdian kepada masyarakat di kalangan masyarakat Sebauk, Tanjungpinang, berikut ini dikemukakan dua saran, yaitu 1) Pendidikan karakter harus lebih intensif disosialisasikan kepada masyarakat Kota Tanjungpinang karena sebagian besar masyarakat belum sepenuhnya memahami cara menerapkannya dalam pendidikan informal di lingkungan keluarga; 2) Nilai-nilai karakter yang terdapat dalam kearifan lokal masyarakat setempat sebaiknya terus digali agar dapat diterapkan dalam implementasi pendidikan karakter di lingkungan keluarga dan 
masyarakat. Dengan demikian, sumber pendidikan karakter benar-benar berasal dari kebudayaan masyarakat sehingga anak-anak tak berasa asing dengan materi yang diterapkan kepada mereka.

\section{Ucapan Terimakasih}

Tim penulis mengucapkan terima kasih dan penghargaan kepada Lembaga Penelitian, Pengabdian Masyarakat dan Penjaminan Mutu (LP3M), Universitas Maritim Raja Ali Haji, yang telah membiayai pelaksanaan kegiatan pengabdian kepada masyarakat ini. Semoga hasilnya bermanfaat bagi masyarakat dan bagi upaya mewujudkan generasi berkarakter baik menyongsong Indonesia Emas 2045.

\section{Referensi}

Departemen Pendidikan Nasional [Depdiknas]. (2003). Undang-Undang No. 20 tahun 2003 Tentang Sistem Pendidikan Nasional. Jakarta, Indonesia: Depdiknas.

Kemendiknas. (2010). Pengembangan pendidikan budaya dan karakter bangsa. Jakarta: Kementerian Pendidikan Nasional.

Kementerian Pendidikan Nasional [Kemendiknas]. (2010). Pengembangan pendidikan budaya dan karakter bangsa. Jakarta: Kementerian Pendidikan Nasional.

Lickona, T. (2004). Pengertian pendidikan karakter. Retrieved from http://belajarpsikologi.com/pengertianpendidikan-

Lickona, T. (2013). Pendidikan karakter: panduan lengkap mendidik siswa menjadi pintar dan baik. Bandung: Ujungberung.

Malik, A. (2014). Kehalusan budi memartabatkan jati diri: Tinjauan karya-karya Raja Ali Haji. Tanjungpinang: Milaz Grafika.

Malik, A. (2015a). Akhak mulia: Tinjauan sastra (dan) agama. Batam: Rizki Fatur Cemerlang.

Malik, A. (2015b). Nilai-nilai budi pekerti dalam karya Raja Ali Haji. Jurnal Peradaban Melayu, 10, 96107.

Malik, A., Harto, Z., \& Saputra, S. D. (2017). Etika perempuan dalam Syair Siti Shianah (karya Raja Ali Haji). Tanjungpinang: Dinas Kebudayaan Provinsi Kepulauan Riau dan Milaz.

Malik, A., \& Shanty, I. L. (2017). Personal character index in the works of Raja Ali Haji. The International Journal of Social Science, 58(1), 22-34.

Malik, A., \& Shanty, I. L. (2019). Character indexes of the people in the works of Raja Ali Haji. In W. Striełkowski \& J. Cheng (Eds.), Advances in social science, education and humanities research. Proceedings of the International Conference on Educational Sciences and Teacher Profession (ICETeP 2018). Atlantis Press.

Pusat Kurikulum. (2010a). Panduan sistem pelatihan pengembangan pendidikan budaya dan karakter bangsa melalui pembelajaran aktif. Jakarta: Badan Penelitian dan Pengembangan, Kementerian Pendidikan Nasional.

Pusat Kurikulum. (2010b). Pedoman pengembangan pendidikan budaya dan karakter bangsa. Jakarta: Badan Penelitian dan Pengembangan, Kementerian Pendidikan Nasional.

Zubaedi. (2013). Desain pendidikan karakter: konsepsi dan aplikasinya dalam lembaga pendidikan. Jakarta: Kencana Prenada Media Grup.

Zuriah, N. (2008). Pendidikan moral dan budi pekerti dalam perspektif perubahan. Jakarta: Bumi Aksara. 